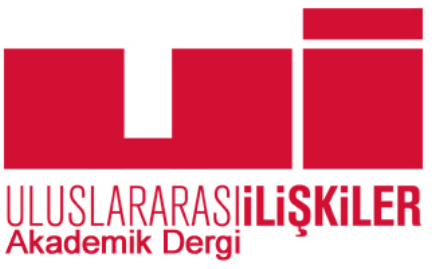

Yayın ilkeleri, izinler ve abonelik hakkında ayrıntılı bilgi:

E-mail: bilgi@uidergisi.com.tr

Web: www.uidergisi.com.tr

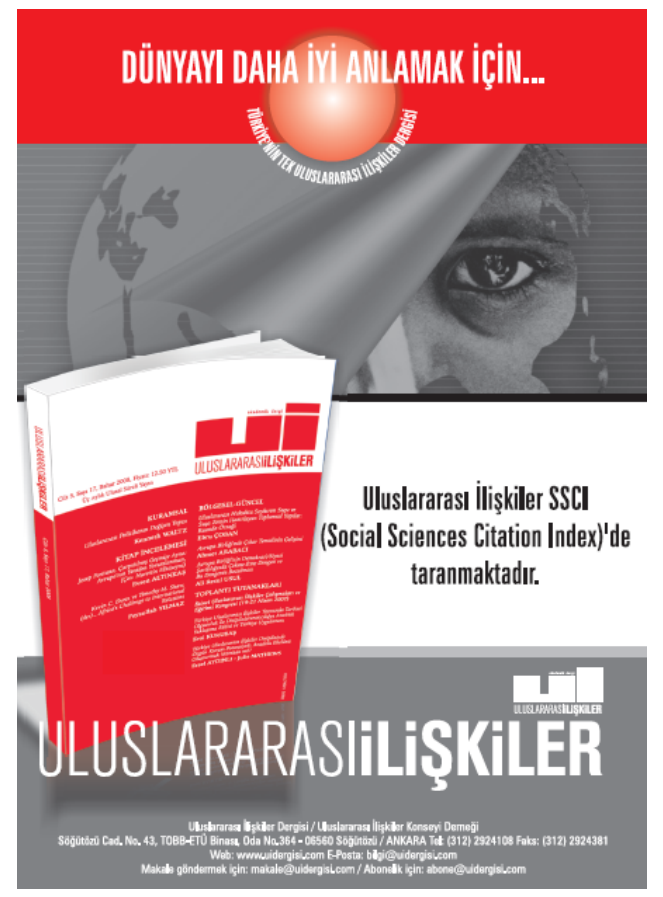

\title{
Sovyetler Birliği’nin Savaş Öncesi Döneme Bakışı (1933-1939): Nazilerin Avrupa'yı İsgalinin Sorumlusu Kim?
}

\section{Umut BEKCAN*}

* Yrd. Doç. Dr., Siyaset Bilimi ve Kamu Yönetimi Bölümü, Pamukkale Üniversitesi

Bu makaleye atıf için: Bekcan, Umut, "Sovyetler Birliği'nin Savaş Öncesi Döneme Baklşı (1933-1939): Nazilerin Avrupa'yı İsgalinin Sorumlusu Kim?”, Uluslararası İlişkiler, Cilt 13, Say1 50, 2016, s. 101-118.

Bu makalenin tüm hakları Uluslararası İlişkiler Konseyi Derneği'ne aittir. Önceden yazılı izin alınmadan hiç bir iletişim, kopyalama ya da yayın sistemi kullanılarak yeniden yayımlanamaz, çoğaltılamaz, dağıtılamaz, satılamaz veya herhangi bir şekilde kamunun ücretli/ücretsiz kullanımına sunulamaz. Akademik ve haber amaçlı kısa alıntılar bu kuralın dışındadır.

Aksi belirtilmediği sürece Uluslararası Illişkiler'de yayınlanan yazılarda belirtilen fikirler yalnızca yazarına/yazarlarına aittir. UİK Derneğini, editörleri ve diğer yazarları bağlamaz. 


\title{
Sovyetler Birliği’nin \\ Savaş Öncesi Döneme Bakışı (1933-1939): \\ Nazilerin Avrupa'yı İşgalinin Sorumlusu Kim?
}

\author{
Umut BEKCAN \\ Yrd. Doç. Dr., Siyaset Bilimi ve Kamu Yönetimi Bölümü, İ̈BF, Pamukkale Üniversitesi, Denizli. \\ E-posta: ubekcan@pau.edu.tr
}

\section{ÖZET}

Bu çalışmada, Sovyetler Birliğinin II. Dünya Savaşı öncesi döneme bakışı, savaşa giden süreci nasıl değerlendirdiği incelenmiştir. Bu döneme Almanya'da iktidara gelen Hitler liderliğindeki Nazi Partisi’nin saldırgan ve yayılmacı dış politikası damgasını vurmuştur. Bu bağlamda çalışmanın temel sorunsalı, Sovyetler Birliği söz konusu dönem boyunca tedricen artan Nazi tehdidini son derece ciddiye alırken, Batılı kapitalist devletler özellikle Milletler Cemiyeti’nin önde gelen iki aktörü İngiltere ve Fransa Nazi Almanya'sına ılımlı yaklaşmıştır. Sovyetler Birliğine göre bunun altında Nazi-Sovyet savaşı ihtimali/beklentisi yatmaktadır. Nazi-Sovyet Paktı ise, Nazilerin Avrupa'yı işgalinin sebebi değil, savaş öncesi dönemde İngiltere ve Fransa’nın güttüğü dış politikanın bir sonucudur.

Anahtar Kelimeler: Sovyetler Birliği, Almanya, II. Dünya Savaşı, Nazi-Sovyet Paktı, Yatıştırma Politikası

\section{The Soviet Union's View of the Pre-war Period (1933-1939): Who is the Responsible for the Nazi Occupation of Europe?}

\begin{abstract}
In the present study, the Soviet Union's view of the period prior to the outbreak of the World War II and how it assessed the process leading to war are examined. Aggressive and expansionist foreign policy of the Nazi Party which came into power under the leadership of Hitler in Germany is of great importance in understanding this period. In this context, the main problematic of the study is that the Soviet Union took the gradually growing Nazi threat extremely seriously, while western capitalist countries especially two leading actors of the League of Nations, England and France were looking moderately upon Nazi Germany, during the said period. According to the Soviet Union, the possibility/expectation of the Nazi-Soviet War lay at the root of this. Also the Nazi-Soviet Pact was not the cause of the Nazi occupation of Europe, but the consequence of the implemented foreign policies of England and France.
\end{abstract}

Keywords: Soviet Union, Germany, World War II, Nazi-Soviet Pact, Appeasement Policy. 


\section{Giriş}

Rusya Devlet Başkanı Vladimir Putin, 5 Kasım 2014'te Moskova'da genç tarihçilerle bir araya geldiği Çağdaş Rusya Tarihi Müzesi’nde yapılan bir toplantıda, savaşın kaçınılmaz olduğunun bilincindeki Sovyetler Birliği'nin zaman kazanmak ve bu arada ordusunu güçlendirmek için Nazi-Sovyet Paktı́nı imzaladığını, bunda kötü ya da yanlış bir şey olmadığını söyledi. 1938'de Çekoslovakya'nın bir kısmının Almanya’ya verilmesini içeren Münih Anlaşması́nın ise Avrupa’yı büyük bir savaşa götürdügünü vurgulayarak isim vermeden savaştan İngiltere ve Fransa'yı sorumlu tuttu. ${ }^{1}$ Sovyetler Birliği'nin (Sovyet, Sovyetler ya da SSCB) savaş öncesi dönemde yaşanan gelişmeler karşısında aldığı pozisyonla örtüşen Putin'in bu sözleri, Marksist-Leninist teoriyi terk eden ardılı Rusya'nın, bu konuda bir paradigma değişikliği yaşamadığının da göstergesiydi. İşte savaş öncesi döneme Sovyet bakış açısını özetleyen bu iddianın dayanakları üzerinde durmak, bu çalışmanın temel amacıdır. Çalışma, Uluslararası İlişkiler disiplininin Siyasi Tarih alanına, gelenekselci yaklaşımı temel alan naçizane bir katkı sağlama niyetindedir. Sander' in belirttiği gibi, tarihin konusunun "biricik" olduğu, bir fizikçinin anladığı anlamda deney yapılamadığı ve dolayısıyla olasılığın olmadığı bilinciyle hareket edilmiştir. ${ }^{2}$

Çalışma, Almanya'da Hitler'in iktidara gelişinden savaşın başlamasına kadarki dönemi kapsamaktadır. Bunun nedeni, Hitler liderliğindeki Nazi Almanya’sının gerçekleştirdiği dış politika yaklaşımının dünyayı savaşa sürüklemesi ve sonunda Polonya’ya saldırarak savaşı başlatmasıdır. II. Dünya Savaşı yeryüzünün gördügü en kanlı, en tahripkâr savaştır. Sovyetler Birliği bu savaşta 27 milyona yakın yurttaşını kaybetmiştir. ${ }^{3}$ Bununla birlikte, savaşın çıkmasında belki de en az sorumluluk sahibi ülkedir. Zira Almanya'da Nazilerin iktidara geldiği andan itibaren Avrupa'nın güvenliğine bir tehdit oluşturduğunun farkında olmuş, bu konuda uluslararası kamuoyunu uyarmış ve muhtemel bir savaşı önlemeye çalışmıştır. Çalışmada, belirtilen dönemde, Sovyetler Birliği'nin Almanya’ya bakışı, tepkisi, uluslararası güvenliğin sağlanmasına yönelik çabası ve İngiltere ile Fransa’nın Almanya’ya yaklaşımları incelenmiş, Nazi-Sovyet Paktı́nın savaşın sorumlusu olup olmadığı tartışılmıştır. Sovyet bakış açısı, ağılıklı olarak SSCB resmi kaynakları ve bu bakış açısının şekillenmesini sağlayan/ şekillenmesine destek olan Batılı kaynaklardan elde edilen bilgiler ve savaş sonrası ortaya çıkan dış politika belgeleri kullanılarak ortaya konulmuştur.

\section{Nazi Tehdidi ve Sovyetler Birliği'nin Barış Politikası}

Hitler liderliğindeki Nasyonal Sosyalist Alman İşçi Partisi (Nazi Partisi) 30 Ocak 1933’te iktidara geldi ve aynı yıl içerisinde dikkat çeken iki önemli gelişme yeni iktidarın eskisine nazaran daha saldırgan bir politika güdeceğinin ipucunu veriyordu. Bunlardan ilki Şubat ayında Alman parlamento binası Reichstag'ın kundaklanması olayıydı. Olayın sorumlusu olarak komünistler gösterildi. Mart ayında Almanya Komünist Partisi kapatıldı. Birçok üyesi hapse atıldı. SSCB'nin Almanya'daki tam yetkili temsilcisi Lev Hinçuk, SSCB dışişleri bakanlığına bunun, seçimlerde komünist partiyi yenilgiye uğratmak isteyen Nazilerin tertibi olduğunu, bu işte Reichstag Başkanı Hermann Göring ile petrol şirketi Royal Dutch Shell'in başkanı Henri Deterding'in parmağı olduğunu, bu konuda Amerikan ve Fransız basınında haberler çıktığını rapor etti. ${ }^{4}$ Yangın sonrası olağanüstü hal ilan edildi. Anayasal

1 "Vstreça c Molodımi Uçonımi i Prepodavatelyami İstorii", http://kremlin.ru/events/president/news/46951 (Erişim Tarihi: 11 Temmuz 2015).

2 Oral Sander, “Tarihte Yöntem”, Ankara Üniversitesi SBF Dergisi, Cilt 28, Sayı 4, 1973, s.60.

3 Sovyetler Birliği, savaşta en fazla insan kaybı yaşayan ülkedir. Michael Ellman ve Sergei Maksudov, "Soviet Deaths in the Great Patriotic War: A Note”, Europe-Asia Studies, Cilt 46, No.4, 1994, s.671-672.

4 Dokumentı Vneşney Politiki SSSR, Tom 16, Moskva, İzdatelskoy Politiçeskoy Literaturı, 1970, s.134, 140; Yabancı basında konuyla ilgili çıkan haberler için bkz. John Donovan, "Evidence of Royal Dutch Shell/Deterding Financial Support for the 
haklar ve özgürlükler askıya alındı. Meclis feshedildi, yeni seçimler yapıldı. Komünistlere yönelik büyük bir baskı dönemi başlarken bu olay Nazilerin iktidarlarını sağlamlaştırma faaliyetlerine bahane teşkil etti. Nisan ayında Almanya, 24 Nisan 1926 tarihli Sovyet-Alman tarafsızlık ve saldırmazlık paktını uzatmadı ve 1922 Rapallo Antlaşması’yla başlayan dönemin sona erdiğini ilan etti. Temmuz ayına gelindiğinde ise tüm siyasal partiler ve sendikalar kapatılmıştı. ${ }^{5}$

İkincisi ise Almanya'nın Ekim ayında silah kısıtlanması konusunda diğer devletlerle eşit hakka sahip olmadığı gerekçesiyle Cenevre Silahsızlanma Konferansı'ndan çekilmesi ve Milletler Cemiyeti'nden (MC) ayrılmasıydı. ${ }^{6}$ Birinci Dünya Savaşı́nın sonunda imzalanan ve Almanya'nın yenilgisini resmileştiren Versay Antlaşması'nın "haksızlık ve adaletsizliklerinden” kurtulma prensibi, Nazilerin dış politikasının temelini oluşturuyordu. Bu da bu politikanın uygulanması yönünde tamirat borçlarını ödememesiyle/ödeyememesiyle birlikte- atılmış önemli bir adımdı.

Sovyetler Birliği, kendisine yönelik hasmane bir davranış görmediği sürece herhangi bir devletle zıtlaşma niyetinde değildi. 29 Aralık 1933’te SSCB Dışişleri Bakanı Maksim Litvinov’un, şu sözleri SSCB'nin dünya devriminden umudunu kestikten sonra uygulamaya başladığı tarafsızlık ve saldırmazlık üzerine kurulu barış politikasıyla uyumluydu:

Alman komünistlerinin çektiği sıkıntıları anlıyoruz ama dış politikamızı duygusallıktan uzak uyguluyoruz. Bütün dünya biliyor ki faşist rejimler de dâhil kapitalist ülkelerle iyi ilişkiler kurmayı destekleyebiliriz, destekliyoruz. Almanya ya da başka bir ülkenin içişlerine karışmıyoruz. Onların içişleri değil dışişleri bizi ilgilendiriyor, ilişkilerimizi dış politika belirliyor. ${ }^{7}$

SSCB lideri Stalin, Ocak 1934'te 17. Parti Kongresi'nde uluslararası alandaki gelişmelerin analizini de içeren bir rapor sundu. Ona göre, emperyalist politikacılar şovenizm ve savaş hazırlığını dış politikanın temel unsuru haline getirirken, cephe gerisini kuvvetlendirmek için içeride işçi sınıfı üzerinde baskı kuruyordu. Sosyalizmle hiç alakası olmadığı gerekçesiyle nasyonal sosyalizm kavramını yanlış bulduğunu söyleyerek Alman tipi faşizmin yükselmesinde sadece işçi sınıfının zayıflı̆̆ının, sosyal-demokratların işçi sınıfına ihanetinin değil burjuvazinin barışçıl bir dış politika uygulayamayacak kadar zayıf olmasının da etkili olduğunu, bunun da burjuvaziyi savaş politikasına yönlendirdiğini belirtiyordu. ${ }^{8}$ Yaklaşan emperyalist savaşın burjuvazi için çok tehlikeli olduğunu ve savaşın ertesinde burjuva devletlerin sayısında bir azalma olabileceğini öngörüyordu. ${ }^{9}$ İtalya ile Eylül 1933'te imzalanan pakta atıfta bulunarak; İtalyan faşizminin bu ülkeyle ilişki kurmak için engel teşkil etmediğini söylerken, Almanya'da da bir süre Ukrayna’yı işgal altında tutan, Leningrad’a karşı bir sefer düzenleyen ve Baltık ülkelerini böyle bir sefer için yığınak bölgesi haline dönüştüren eski Alman İmparatoru'nun politikasının ağılık kazanmaya başladığına dikkat çekiyordu. Versay Antlaşması́nı hiçbir zaman haklı görmediklerini ama bu antlaşma yüzünden dünyanın savaşa sürüklenmesini de kesinlikle istemediklerini özellikle belirtiyor, barışın korunması ve tüm ülkelerle ticari ilişkilerin güçlendirilmesi şeklinde açık bir dış politikalarının olduğunu ifade ediyordu. ${ }^{10}$

Nazis", http://royaldutchshellplc.com/2010/11/06/royal-dutch-shell-and-the-nazis-part-5-evidence-of-shelldeterdingfinancial-support-for-the-nazis-2/ (Erişim Tarihi: 11 Temmuz 2015); “Sir H. Deterding, 72 Dies in Swiss Home”, http:// royaldutchshellplc.com/1939/02/06/sir-h-deterding-72-dies-in-swiss-home/ (Erişim Tarihi: 11 Temmuz 2015).

5 Andrey Sidorov ve Nadejda Kleymenova, İstoriya Mejdunarodnı Otnoşeniy 1918-1939, Tsentrpoligraf, Moskva, 2008, s.176, 178.

6 Kissinger’a göre, Hitler, diğer devletlerle eşit hakka sahip olmadığından dolayı değil, aksine Almanya’nın eşitlik talebinin kabul edilmesinden ve silahlanmasına engel olunacağından korktuğu için konferanstan ve MC'den çekilmişti. Henry Kissinger, Diplomasi, İbrahim H. Kurt (Çev.), Türkiye İş Bankası Kültür Yayınları, İstanbul, 2007, s.286.

7 Dokumentı Vneşney Politiki SSSR, Tom 16, s. 792.

8 Josef Stalin, Leninizmin Sorunları, İ. Yarkın, S. Kaya, S. N. Kaya (Çev.), İnter Yayınları, İstanbul,1997, s.549-550.

9 Ibid., s.552.

10 Ibid., s.556-557, 559. 
SSCB’nin barış temalı dış politika stratejisinin yol haritası, Stalin'in çizdiği bu çerçeve içerisinde, Parti'nin Merkez Komitesi Politbürosu tarafından 19 Aralık 1933’te belirlenmişti. Almanya'nın saldırganlığına karşı bölgesel karşılıklı yardım antlaşması imzalanması ve bu antlaşmaya Belçika, Çekoslovakya, Litvanya, Letonya, Estonya, Finlandiya'nın ya da bu ülkelerden bazılarının, Fransa ve Polonya'nın ise mutlaka katılması gerektiği fikrindeydi. ${ }^{11}$ Fransa'yla SSCB arasında Almanya'nın MC'den ayrılmasından sonra bir yakınlaşma süreci başlamıştı. İki ülkenin gündeminde saldırmazlık antlaşması, karşılıklı yardım ve SSCB'nin MC'ye girmesi konuları vardı. ${ }^{12}$ Fransa Dışişleri Bakanı Louis Barthou, temel olarak, 1925’te imzalanan Almanya'nın Belçika ve Fransa sınırlarını güvence altına alan Locarno Antlaşmalarını; Almanya'nın Çekoslovakya, SSCB ve Baltık devletleri ile olan sınırlarını da kapsayacak bir şekilde genişletmek niyetindeydi. Söz konusu doğu paktının üyeleri, herhangi bir imzacı devlete saldırı olduğunda birbirlerine askeri yardım da dâhil olmak üzere destek olacaklardı. ${ }^{13}$ SSCB, Barthou'nun önerisini memnuniyetle karşılamıştı. ${ }^{14}$ Barthou da Fransa'nın SSCB'yle yakınlaşma niyetinde olduğunu ve SSCB'nin MC'de yer alması gerektiğini düşünüyordu. ${ }^{15}$ Ne var ki, pakt gerçekleşmedi. Bir kere, Almanya Dışişleri Bakanı Konstantin von Neurath paktı kabul edilemez buluyordu. Almanya silahsızdı, kendisi ve diğer ülkelerin savunulması için yeterli gücü yoktu. Ayrıca, Almanya'da doğuya yayılma hayali kuran aptalların olabileceğini ama hükümetinin böyle bir düşüncesinin olmadığını, Alman saldırganlığıyla ilgili şüpheleri temelsiz bulduğunu söylüyordu. ${ }^{16}$ Bunun dışında, Finlandiya ve Polonya da pakta olumsuz yaklaşıyordu. Sovyet Dışişleri Bakanlığı, bunun sebebini, SSCB'ye yönelik muhtemel bir saldırıdan kazanım elde etme beklentisi olarak görüyordu. ${ }^{17}$ Dışişleri Bakanı John Simon, 13 Temmuz 1934'te Avam Kamarası’nda yaptığı konuşmada İngiltere'nin, Almanya'nın çevrelenmesine neden olacak bir faaliyet içerisinde olmayacağını, Avrupa devletleri arasında yapılan bütün anlaşmaların Almanya'ya hak eşitliği sağlayacak şekilde yorumlanması gerektiğini söyledi. ${ }^{18}$ Böylelikle, doğu paktı için umutlar tükenirken Sovyetler Birliği, Fransa'nın girişimi sonucu kendisine yapılan çağrıya kayıtsız kalmıyor ve 18 Eylül 1934'te MC'ye giriyordu. Sovyetler, barışın korunması, güçlendirilmesi hususunda aynı fikirde olduğu ülkelerle birlikte mücadele etmek amacıyla örgüte üye olmuştu. ${ }^{19}$ Kolektif güvenlik fikrinde ssrarlıydı, doğu paktından kolay kolay vazgeçmek istemiyordu. Almanya'sız ve Polonyasız, Fransa ve Çekoslovakya'yla ya da sadece Fransa'yla antlaşma yapılabileceğini, ${ }^{20}$ Almanya’nın söz konusu pakta dâhil olmak istememesinden İngiltere'nin sorumlu olduğunu düşünüyordu. ${ }^{21}$ Neticede Sovyetler 2 Mayıs 1935'te Fransa'yla bir karşılıklı yardım antlaşması imzalamayı başardı. Beş yıl geçerliliği olan antlaşma, bir

11 Politbüro TsK RKP(B)-VKP(B) i Yevropa, Reşeniya Osoboy Papki 1923-1939, Rosspen, Moskva, 2001, s.305.

12 Sidorov ve Kleymenova, Ístoriya , s.185; Dokumentı Vneşney Politiki SSSR, Tom 16, s.595.

13 Anna Pankratova, “Obrazovaniye Vtorogo Oçaga Voynı v Yevrope 1933-1935 gg.", İstoriya Diplomatii, Tom 3, red. Vladimir Potemkin, Gosudarstvennoye İzdatelstvo Politiçeskoy Literaturı, Moskva-Leningrad, 1945, s.500-501.

14 Hatta SSCB, Mart 1934'te Almanya’ya Baltık ülkelerinin bağımsızlığına ve toprak bütünlügüne zarar verecek bir faaliyette bulunmamayı taahhüt eden bir protokol imzalamayı önerdi ama Almanya buna yanaşmadı. Ibid., s.503.

15 “Franko-Sovetskiye Otnoşeniya i Borba Za Mir”, Pravda, 28 Mayıs 1934, s.1.

16 Dokumentı Vneşney Politiki SSSR, Tom 17, İzdatelstvo Politiçeskoy Literaturı, Moskva,1971, s.386-387.

17 Ibid., s.373.

18 Simon, Almanya’ya bütün ulusların güvenliğini sağlayan sistem içerisinde diğer ülkelerle eşit kılan 11 Aralık 1932 tarihli, Almanya’nın yanı sıra İngiltere, Fransa, İtalya ve ABD tarafindan imzalanan deklarasyona atıfta bulunuyordu. Pankratova, "Obrazovaniye", s.503-504.

19 "Vstupleniye SSSR V Ligu Natsiy”, Izvestiya, 20 Eylül 1934, s.1.

20 Politbüro TsK RKP(B)-VKP(B), s.318-319.

21 Dokumentı Vneşney Politiki SSSR, Tom 18, İzdatelstvo Politiçeskoy Literaturı, Moskva, 1973, s.112; Paktın gerçekleşmesi konusunda umutları tamamen bitiren gelişme Fransa Dışişleri Bakanı Barthou'nun Ekim ayında bir suikast sonucunda öldürülmesiydi. Pankratova, “Obrazovaniye”, s.507. 
Avrupa devletinden saldırı gelmesi durumunda tarafların karşılıklı yardımını öngörüyordu ${ }^{22}$ Fransa, Japonya ya da bir başka Avrupalı olmayan devletin SSCB’ye saldırması durumunda yükümlülük altına girmek istemiyordu. İmzalanan ek protokolde antlaşmanın Almanya, Polonya, Çekoslovakya, Baltık devletlerini içine alan güvenlik antlaşması müzakerelerinin sonucunda gerçekleştirildiği belirtilerek özellikle Almanya'yla uzlaşma umudu korunuyordu. ${ }^{23} 16$ Mayıs'ta ise, SSCB ile Çekoslovakya arasında karşılıklı yardım antlaşması imzalandı. Pakt, taraflardan biri saldırıya uğradığında, diğerinin yapacağı yardımın en fazla Fransa'nın yapacağı yardım kadar olması üzerine kuruluydu. ${ }^{24}$ Tabii bu durum, antlaşmanın etkisinin ve samimiyetinin sorgulanmasına neden oluyordu. Aslında benzer bir sorun SSCB-Fransa antlaşmasında da vardı. Muhtemel bir saldırıda bir tarafın diğerine yapacağı yardım belirsizdi. Ortak sınır yoktu. Sovyet Dışişleri Bakanı Litvinov, antlaşmanın Almanya’nın saldırı ihtimalini azaltan siyasi bir anlam taşıdığı görüşündeydi. ${ }^{25}$

SSCB’nin barışı koruma/savaştan kaçınma ve kolektif güvenliği sağlama adına yaptığı bir başka girişim ise, 25 Temmuz-20 Ağustos 1935 'te Moskova'da toplanan Komintern'in 7. Kongresi'nde komünist partilere burjuvaziyle ve sosyal demokratlarla geniş bir siyasi koalisyon, birleşik bir cephe kurmaları çağrısı yapılmasıydı. Faşist diktatörlere karşı barışı savunmak, demokratik özgürlügü korumak amaçlandı. ${ }^{26}$ Ekim ayında İtalya’nın Habeşistan'ı işgal etmesi Sovyetlere göre MC’nin eksikliğini ortaya koyuyordu, örgüt savaşı önlemek için hiçbir tedbir almamıştı. Bu işgalle bütün Avrupa'yı saracak bir dünya savaşı tehlikesi giderek artıyordu. ${ }^{27}$

\section{Nazilerin Dış Politikası: Versay'dan Kurtulma ve Yayılma}

Sovyetler Birliği’nin kolektif güvenliği sağlama çabalarına karşı Almanya’nın ilk önemli hamlesi 26 Ocak 1934’te Polonya ile imzaladığı saldırmazlık paktı oldu. Böylece, Polonya’nın Fransa ve SSCB ile yakınlaşması önlendi. ${ }^{28}$ Bununla birlikte Almanya için en az kolektif güvenliğe karşı takındığı tutum kadar (belki ondan daha fazla) önemli bir başka husus silahlanma meselesiydi. Almanlar, Versay Antlaşması'nın askeri hükümlerinin ülke savunmasını zayıf bıraktığını düşünüyordu. Savunma Bakanı Hermann Goering'e göre, Almanya’nın, komşularının sahip olduğu hava gücünün \%30-40'ı oranında bir hava savunma filosuna sahip olması gerekiyordu. Almanya 29 Mart'ta, 1934-1935 dönemi askeri bütçesini yayımladı. Buna göre, havacılık harcamalarında 2,5, Versay’a göre sınırlandırılan ve ağır silahlardan yoksun ordunun (Reichswehr) harcamalarında ise 1,5 kattan fazla artış öngörülüyordu. ${ }^{29}$ Zaten müttefiklerce Versay çerçevesinde kurulmasına izin verilen küçük askeri fabrikalar üretimini artırmış ve genişletmişti. Silahlar Alman firmalarının yabancı ülkelerdeki şubelerinde üretiliyordu ve 1 Mart 1935 itibariyle Almanya bir hava bombardıman filosuna da sahip olmuştu. ${ }^{30} 16$ Mart'ta genel askerlik hizmetini yürürlüğe sokan Almanya, Versay Antlaşması’ndan dolayı küçük düştügünü, ulusal gururunun incindiğini öne sürerek sınırlarının güvenliği için hak eşitliği talep ediyordu. ${ }^{31}$

22 Dokumentı Vneşney Politiki SSSR, Tom 18, s.309-310.

23 Ibid., s.312

24 Ibid., s.336.

25 Ibid., s.292.

26 VII Kongress Kommunistiçeskogo Internatsionala i Borba Protiv Faşizma i Voynı, İzdatelstvo Politiçeskoy Literaturı, 1975, Moskva, s.137.

27 Vyaçeslav Molotov, Stati i Reçi 1935-1936, Partizdat TsK VKP(B), 1937, Moskva, s.177.

28 Pankratova, “Obrazovaniye”, s.487.

29 Ibid., s.499.

30 Anna Pankratova, "Vozniknoveniye Tretyego Oçaga Voynı i Dalneyşee Nastupleniye Podjigateley Voynı 1935-1936 gg.", Istoriya Diplomatii, Tom 3, s.521-522.

31 Ibid., s.524, 527. 
SSCB, Almanya'nın silahlanmasına göz yumulmasından da rahatsızdı. Litvinov, 28 Mart 1935'te İngiltere Dışişleri Bakanı Anthony Eden'e, Hitler’in Batı ülkelerini “yemlediğini”, silahlanma istenilen seviyeye ulaştığında silahların tamamen başka bir istikamete ateşleneceğini iddia ederek SSCB’nin bu rahatsızlı̆̆ını ve öngörüsünü dile getiriyordu. ${ }^{32}$

Almanya’nın silahlanmasına göz yuman İngiltere ise, bunu kendi kontrolünde tutmayı ve hukuki bir temele oturtmayı denedi. Bu çerçevede 18 Haziran 1935'te İngiltere ile Almanya arasında imzalanan Deniz Anlaşması, Alman savaş gemilerinin toplam tonajının İngiliz savaş gemilerinin toplam tonajının \%35'i, Versay’a göre yasaklanan denizaltı filosunun ise İngiltere'nin sahip olduğu tonajın \% 45 'i oranında olmasını içeriyordu. İngiltere'nin Fransa'ya danışmadan yaptığı bu anlaşma sayesinde Alman ve Fransız donanması hemen hemen eşit hale geliyor, hatta Alman donanması teknik olarak daha üstün duruma geçiyordu..$^{33}$ Tabii bu anlaşma Nisan ayında İngiltere, Fransa ve İtalya tarafından Almanya'nın barışı tehdit eden davranışlarına karşı ortak hareket etmek amacıyla oluşturulan Stresa Cephesi'ni de derinden yaralıyordu. Ekim ayında (Stresa'ya öldürücü darbeyi vuran) İtalya'nın Habeşistan'ı işgaline karşı MC'nin etkili tedbirler alamaması, Nazi iktidarının cesaretini artırıcı bir etki yaptı. Şubat 1936'da Hitler, Fransa' yla yakınlaşmaya hazır olduğunu fakat SSCB-Fransa Antlaşması'nın engel oluşturduğunu, bu antlaşmanın SSCB’nin Avrupa halklarını birbirine düşürme amacına hizmet ettiğini söyleyerek ${ }^{34}$ komşusuna deyim yerindeyse "şirin görünmeye" çalışıyordu. Kısa bir süre sonra (7 Mart'ta) Versay’a göre silahsızlandırılan Ren bölgesini işgal eden Almanya, Locarno Antlaşmalarına da aykırı hareket etmiş oluyordu. Bu hareketini, SSCB-Fransa Antlaşması'na (Mayıs 1935) bir cevap oluşturduğunu söyleyerek Sovyetler Birliği’ne duyulan güvensizliği kullanıyor, ${ }^{35}$ İngiltere ve Fransa'nın muhtemel bir olumsuz tepkisini de önlemeye çalışıyordu. Bununla birlikte, Fransa ve Belçika'yla 25 yıl süreli bir saldırmazlık paktı imzalamaya hazır olduğunu bildirerek Batı’yla bir probleminin olmadığı izlenimi veriyor, işgalin olumsuz etkisini gidermeye çalışıyordu. Locarno'nun garantörü İngiltere ise bunu bir saldırı olarak değerlendirmedi. Almanya'ya karşı askeri, ekonomik herhangi bir yaptırım uygulanmasına engel olmak için çaba gösterdi. Fransız hükümeti pasif kaldı, savaşı göze alamadı. MC Konseyi ve Locarno Antlaşmaları’nı imzalayan devletler arasında yapılacak bir konferansla işgal sonucu ortaya çıkan durumun incelenmesi gerektiğini düşünüyordu. ${ }^{36}$

SSCB Dışişleri Bakanı Maksim Litvinov, 17 Mart 1936'da MC Konseyi toplantısında örgütün etkisizliğini eleştiriyor, Hitler'in SSCB-Fransa Antlaşması'nın Locarno'ya aykırı olduğu iddiasına karşı çıkıyordu. SSCB ve Fransa’nın herhangi bir sınır değişikliği talebi olmadığını, Almanya saldırmadığı sürece SSCB-Fransa Antlaşması’nın da bir anlamı olmadığını ifade ediyor, Alman dış politikasının saldırgan bir nitelik taşıdığını ve SSCB’ye karşı bir saldırı hazırlığında olduğunu açıkça vurguluyordu. ${ }^{37}$ Almanya Dışş̧leri Bakanı Joachim von Ribbentrop’a göre MC, Versay’ın Avrupa barışını tehdit eden

32 Dokumentı Vneşney Politiki SSSR, Tom 18, s.235.

33 Pankratova, "Vozniknoveniye”, s.547-548; Churchill, İngiltere’nin Almanya’nın zorunlu askerlik hizmetini yürürlüğe koymasına göz yumduğuna ve ayrıca Almanya’yla yaptığı deniz anlaşmasına dikkat çekerek Hitler'in hamlelerine direnç gösterilmediğini belirtiyordu. Ona göre barış için savaş, 1935’te kazanılabilirdi ama bu politikayla kaybedilmişti. Winston Churchill, The Gathering Storm, Rosettabooks, New York, 2002, s.230.

34 Anna Pankratova, "Politika 'Nevmeşatelstva' Demokratiçeskih Pravitelstv Yevropı 1935-1937 gg.", İstoriya Diplomatii, Tom 3, s.556.

35 Kissinger, Diplomasi, s.296.

36 Pankratova, "Politika”, s.558-560; Kissinger, Diplomasi, s.299; Sidorov ve Kleymenova, İstoriya, s.216; Fransa, İngiltere ile ittifak yapmadan Almanya yla savaşa girmeme üzerine bir politika güdüyordu. İşgalden beş ay sonra (Ağustos 1936) Fransa Başbakanı Leon Blum, Almanya Ekonomi Bakanı Hjalmar Schacht'a "Ben hem Marksist hem Yahudi'yim fakat ideolojik engelleri aşılmaz kabul edersek hiçbir şey yapamayız.” dedi. Bu ifade, Fransa’nın savaşı önlemek için Almanya’ya ödünler vermeye razı olduğu anlamını taşıyordu. Kissinger, Diplomasi, s.296-297, 301.

37 Dokumentı Vneşney Politiki SSSR, Tom 19, İzdatelstvo Politiçeskoy Literaturı, Moskva,1974, s.154-156. 
kalıntılarını ortadan kaldıran Almanya'ya şükran duymalıydı. Buna karşılık MC Konseyi ise, işgalin Versay ve Locarno antlaşmalarına aykırı olduğunu belirten bir karar almakla yetindi. ${ }^{38}$

Almanya'nın saldırgan politikası Temmuz 1936'da başlayan İspanya İç Savaşı sırasında da devam etti. Bu kez yalnız değildi, İtalya da İspanya’nın meşru halk cephesi hükümetine yönelik faşist General Franco liderliğindeki ayaklanmaya Almanya'yla birlikte destek oldu. Hatta iki ülke bu iç savaşa kara ve hava güçleriyle katıldılar. ${ }^{39}$ İniltere ve Fransa ise pasif tutumlarını sürdürdü. Müdahale Etmeme Anlaşması sonrası oluşturulan Müdahale Etmeme Komitesi deyim yerindeyse "müdahale edenlere müdahale etmeme” komitesine dönüştü. Sovyetler Birliği; İngiltere ve Fransa’nın İspanya hükümetine yardım etmek istemediği, söz konusu komiteyle bunu meşru bir zemine oturttukları fikrine sahipti. ${ }^{40}$ Muhtemelen İngiltere, İspanya'da faşist bir rejimi, SSCB’ye bağlı sol bir hükümetten daha az tehlikeli görüyordu. ${ }^{41}$

Ekim ayında SSCB, Müdahale Etmeme Komitesi’ne, Almanya ve İtalya'nın müdahalelerinin yapılan anlaşmayı boş bir kâğıt parçasına dönüştürdüğünü, bu şartlarda uluslararası hukuka uygun olarak iç savaşa karışmama yükümlülükleri yerine getirilene kadar, SSCB’nin kendini isyancı generalleri destekleyen ülkelerden daha fazla bu anlaşmaya bağlı hissetmeme hakkı olduğunu bildirdi. ${ }^{42}$ Sovyetler, İspanya’nın faşist baskıdan kurtarılmasının sadece İspanya’nın değil tüm öncü ve ilerici insanlığın görevi olduğunu düşünüyordu..$^{43} \mathrm{Ne}$ var ki, iç savaşı solcular kaybedecek, faşistler İspanya'ya egemen olacaktı. İç savaşta, İngiltere ve Fransa, Almanya’nın solculara düşman olduğunu görmüştü. İki devlet bundan rahatsız değildi. Solculara yardım ederek Almanların düşmanlığını kazanmaya gerek yoktu. Sovyetlere göre, İngiltere ve Fransa'nın işe karışmaması Almanya ve İtalya destekli faşistlerin kazanmasına neden olmuştu. Daha sonra ortaya çıkan belgeler Sovyetler Birliği’ni haklı çıkarıyordu. Örneğin, İngiltere parlamentosunun Lordlar Kamarası Başkanı Lord Halifax ile Hitler’in 19 Kasım 1937 tarihli görüşmesi (İspanya İç Savaşı́nın devam ettiği dönemde) iki devletin en önemli sorun olarak SSCB'yi gördüklerini ortaya koyuyordu. Halifax görüşmede, Hitler'in Almanya'da "komünizmi yok etmek" için yaptığ1 hizmetlerden söz ederek, bu ülkeyi “Bolşevizm karşıtı Batı’nın kalesi” olarak niteliyordu. ${ }^{44}$ Alman-İngiliz yakınlaşmasının Berlin-Roma mihverine ya da Londra-Paris arasındaki iyi ilişkilere zarar verebileceği

38 Pankratova, "Politika", s.563.

39 Bu konuda bkz. Sosyalizm ve Toplumsal Mücadeleler Ansiklopedisi, Cilt 3, İstanbul, İletişim Yayınları, 1988, s.861-862, 864; Edward Hallett Carr, Komintern ve İspanya İç Savaşı, Ali Selman (Çev), İletişim Yayınları, İstanbul, 2010, s.59-64, 94, 106-108.

40 Dokumentı Vneşney Politiki SSSR, Tom 19, s.459.

41 Kissinger, Diplomasi, s.302; Carr’a göre, İngiltere Başbakanı Chamberlain, Haziran 1937'de Avam Kamarası'nda yaptığı konuşmada, cumhuriyetçi İspanyol hükümetine karşı sempati veya destek ifade etmekten kasıtlı olarak kaçınmış ve amaçlarının savaşı İspanya sınırlarına hapsederek Avrupa barışını sağlamak olduğunu belirtmişti. Carr, Komintern ve İspanya İ̧̧ Savaşı, s.109.

42 Dokumentı Vneşney Politiki SSSR, Tom 19, s.464, 514-515.

43 Stalin, İspanya Komünist Partisi Genel Sekreteri Jose Diaz Ramos’a gönderdiği telgrafta, Sovyet emekçilerinin İspanya’nın devrimci kitlelerine elinden gelen yardımı yaptığını belirtti. "Tsentralnomu Komitetu Kommunistiçeskoy Partii İspanii Tovarişu Hoze Dias”, Pravda, 16 Ekim 1936, s.1; Sovyet askeri desteğinin yanı sıra Komintern’in çabasıyla 54 ülkeden 40.000'den fazla gönüllü, faşist ayaklanmacılara karşı savaşmaya gitti. Ayrıca Aralık 1936'da İspanya'nın Ekim Devrimi yoluna girmesini reddeden, parlamenter yapının korunmasının tercih edildiğini ifade eden bir mektup da gönderildi. Sidorov ve Kleymenova, İstoriya, s.232-233.

44 Dokumentı i Materialı Kanuna Vtoroy Mirovoy Voyn 1937-1939, Tom 1, Moskva, Politizdat, 1981, s.35; Bu noktada, Kasım 1936'da Almanya ile Japonya arasında Sovyet karşıtı Antikomintern Pakt'ın imzalandığını ve İtalya'nın da Kasım 1937'de bu pakta dâhil olduğunu belirtmek gerekir. Bu pakt, yayılmacı jeopolitik amaçların antikomünist sloganlar altında gizlenmesi işlevi görüyordu. Mihail Myagkov, "Ot Myunhenskogo Soglaşeniya Do Sovetsko-Germanskogo Dogovora Ot 23 Avgusta 1939 g.: Predistoriya Voprosa”, Mejdunarodnıy Krizis 1939-1941 gg.: Ot Sovetsko-Germanskih Dogovorov 1939 Goda Do Hapadeniya Germanii Na SSSR, (red.) N. Yegorova, A. Zagorskiy et.al., İzdatelstvo Prava Çeloveka, Moskva, 2006, s.50. 
şeklinde bir algının oluşmaması gerektiğini belirtirken Versay diktasının hatalarının düzeltilmesi gerektiğinin altını çiziyordu. Bu noktada Ren bölgesinin (1923'te Fransa tarafından) işgalinin sonlandırılmasında, tamirat borçları sorununun çözümünde ve Ren bölgesinin (Almanlar tarafından) işgal edilmesinde İngiltere'nin oynadığı role işaret etti. ${ }^{45}$ Ayrıca Danzig (Gdansk), Avusturya ve Çekoslovakya ile ilgili değişikliklerin barış̧̧ıl evrim yoluyla gerçekleştirilmesine, Almanya ve diğer ülkeler gibi geniş çaplı huzursuzluklara yol açacak yöntemlerden uzak durmaya önem verdiğini söyleyerek bir bakıma Hitler' in söz konusu yerleri ele geçirme planlarına karşı olmayacağını açılklamış oldu ${ }^{46}$ Halifax'ın açıklamalarından memnun olan Hitler ise, Avrupa için tek felaketin Bolşevizm olduğunu söylüyor, geri kalanları çözülebilir nitelikte görüyordu. ${ }^{47}$

“Çözülebilir” sorunlardan ilki Avusturya’ydı. Hitler, tüm Almanları aynı devlet altında toplamak ve buna uygun olarak Avusturya'yı ilhak etmek istiyordu. 1934’te Avusturya Nazilerinin darbe girişimi başarısızlıkla sonuçlanmıştı. Ama şimdi Almanya hem daha güçlüydü hem de Birinci Dünya Savaşı sonrası düzenin başta gelen mimarı, statükonun savunucusu İngiltere'nin onayını almıştı. İngiltere Maliye Bakanı (Mayıs 1937'den itibaren) John Simon 21 Şubat 1938'de Avam Kamarası'nda, İngiltere'nin Avusturya'nın bağımsızlı̆g i ç̧in bir güvence vermediğini belirtti. ${ }^{48}$ Ertesi gün ise, yine Avam Kamarası́nda adı yatıştırma politikasıyla özdeşleşen Başbakan Neville Chamberlain, küçük ulusların herhangi bir saldırıda kendilerini MC'nin koruyacağını düşünmelerine neden olacak eylemlerde bulunmamak gerektiğini söyledi. ${ }^{49} \mathrm{Bu}$ ifadeler, 20 Şubat'ta Hitler'in Reichstag'da "Almanya, iki komşu ülkede yaşayan 10 milyon Almanın kaderiyle ilgili kayıtsı kalamaz" ${ }^{50}$ şeklindeki çıkışının ardından İngiltere’nin, Almanya'nın Avusturya'yı ilhakına ve Çekoslovakya ile ilgili politikasına karşı çıkmayacağını belli ediyordu. 3 Mart'ta İngiltere’nin Berlin Büyükelçisi Nevile Henderson, Hitler ve Alman Dışişleri Bakanı Ribbentrop'la yaptığı gizli görüşmede ticari bir alışveriş amacında değil, Almanya ile gerçek ve gönülden bir dostluğun temelini oluşturma çabasında olduklarını ve Chamberlain'in büyük bir cesaretle kolektif güvenlik gibi oluşumların maskesini indirdiğini söyledi. ${ }^{51}$ Kısa bir süre sonra, 12 Mart'ta Almanya Avusturya’yı ilhak etti. Sovyetler Birliği, saldırının daha fazla genişlemesinin önlenmesi hususunu ve diğer ülkelerle birlikte alınacak tedbirleri görüşmeye hazır olduğunu bildirirken, ${ }^{52}$ İngiltere Hükümeti buna cevaben saldırıya karşı koordineli bir eylem amacıyla yapılacak bir konferansın Avrupa barışına katkı sağlamayacağı fikrini savunuyordu. ${ }^{53}$ İniltere ve Fransa doğuya doğru bu hamleden rahatsızlık duymuyordu ve konunun MC gündemine gelmesine bile engel olmuştu. ${ }^{54}$

Almanya’nın sıradaki hedefi Çekoslovakya’ydı. Çekoslovakya’nın 2,5 milyon Almanın yaşadığı Südetler bölgesini topraklarına katmak istiyordu. Böyle bir durumda SSCB, Mayıs 1935'te imzalanan antlaşmadan doğan yükümlülügüne uygun olarak, Çekoslovakya'nın güvenliğini sağlama ve toprak bütünlügünü koruma amacıyla yardım etme niyetindeydi. ${ }^{55} \mathrm{Ne}$ var ki 30 Mayıs 1938 'de Çekoslovakya Dışişleri Bakanı Kamil Krofta, SSCB’nin Prag Büyükelçisi Sergey Aleksandrovskiy’e Fransa yardım

45 Dokumentı i Materialı Kanuna Vtoroy Mirovoy Voynı 1937-1939, Tom 1, s.36-37.

46 Ibid., s.42.

47 Ibid., s.45.

48 Carroll Quigley, The Anglo-American Establishment, Books in Focus, New York, 1981, s.277.

49 "Foreign Affairs", http://hansard.millbanksystems.com/commons/1938/feb/22/foreign-affairs\#S5CV0332P0_19380222_ HOC_313 (Erişim Tarihi: 11 Temmuz 2015)

50 Anna Pankratova, “Zahvat Avstrii i Rasçleneniye Çehoslovakii Faşistskoy Germaniyey 1938 g.", Istoriya Diplomatii, Tom 3, s.614.

51 Dokumentı i Materialı Kanuna Vtoroy Mirovoy Voynı 1937-1939, Tom 1, s.53-54, 57.

52 Dokumentı Vneşney Politiki SSSR, Tom 21, Moskva, İzdatelstvo Politiçeskoy Literaturı, 1977, s.128-129.

53 Dokumentı i Materialı Kanuna Vtoroy Mirovoy Voynı 1937-1939, Tom 1, s.80-81.

54 Sidorov ve Kleymenova, İstoriya, s.245.

55 Dokumentı Po İstorii Myunhenskogo Sgovora 1937-1939, Moskva, İzdatelstvo Politiçeskoy Literaturı, 1979, s.57, 87. 
etmediği takdirde SSCB'den yardım almayı düşünmediklerini bildirdi. ${ }^{56}$ Fransa ise, doğuya yönelen Almanya'nın yoluna taş koyup düşmanlığını kazanmayı, batıya dönmesini istemiyordu. Antlaşmaya rağmen Çekoslovakya'ya yardım etmeye pek niyetli değildi. ${ }^{57}$ SSCB Dışişleri Bakan Yardımcısı Vladimir Potemkin'e göre Fransa son derece gergin uluslararası ortama rağmen kararsızlık ve eylemsizlik içerisindeydi ve bu hem kendisi hem de Avrupa için tehlikeli bir durum yaratıyordu. ${ }^{58}$ 17 Ağustos 1938'de İngiltere'deki Sovyet Büyükelçisi İvan Mayskiy, İngiltere Dışişleri Bakanı (Şubat 1938'den itibaren) Lord Halifax’a SSCB’nin İngiltere ve Fransa’nın uyguladığı zayıf ve uzağı göremeyen politikadan duyduğu hayal kırıklığını iletti. Bu politikanın saldırıyı bir sonraki aşamaya atlattığını ve Batılı ülkelerin yaklaşan yeni bir dünya savaşından sorumlu olduğunu da ekledi. Mayskiy’in bildirdiğine göre Halifax, bu sözlere itiraz etmemiş, ülkesinin politik çizgisini savunan bir ifadede bulunmamıştı. Durumun çok ciddi olduğunu, Südet Almanlarıyla Çekoslovakya Hükümeti’nin anlaşacaklarına dair çok az umudunun olduğunu ve her şeyin Hitler'e bağlı olduğunu söylemekle yetinmişti. ${ }^{59}$ Litvinov 22 Ağustos'ta, Fransa Çekoslovakya'da Alman saldırısına karşı durduğu takdirde İngiltere'nin pozisyonu ne olursa olsun Fransa'yı yardımsız bırakmayacaklarını belirten bir telgrafı Prag'taki Sovyet elçiliğine gönderdi. ${ }^{60}$ Almanya ise bu konuda İngiltere'nin yoluna taş koymayacağından emindi. Almanya’nın Londra Büyükelçisi Herbert von Dirksen, 10 Temmuz 1938'de Berlin'e, İngiliz Hükümeti’nin; SSCB'nin Avrupa siyasetinden dışlanması, MC'nin etkisinin zayıflatılması ve amaca uygun ikili görüşme ve anlaşmaların yapılması gibi temel konularda Almanya'ya yakın durduğunu bildiriyordu. ${ }^{61}$

Almanya beklediği sonuca 29 Eylül 1938'de Münih’te ulaştı. Dört devlet (İngiltere, Fransa, İtalya, Almanya) Çekoslovakya’nın iradesini dikkate almadan Südetler bölgesinin Almanya'ya verilmesine karar verdi. Sovyetler Birliği'nin Çekoslovakya'ya yardım etmesi için Polonya veya Romanya'dan geçmesi gerekiyordu. Polonya, Berlin ve Moskova'ya eşit mesafede durduğunu, ${ }^{62}$ Sovyet askerlerinin topraklarından geçmesinin söz konusu olamayacağını bildirince, Sovyet Hükümeti 23 Eylül'de, Çekoslovakya'ya bir saldırı olduğu takdirde Polonya topraklarından Çekoslovakya' ya geçmek için 25 Temmuz 1932 tarihli SSCB-Polonya saldırmazlık paktını feshedeceğini bildirerek bu ülkeye gözdağı verdi. ${ }^{63}$ Romanya ise, Fransa'nın Çekoslovakya'ya yardım etmesi ve MC'nin Almanya'yı saldırgan ilan etmesi durumunda Sovyet askerlerinin topraklarından geçmesine izin verme niyetindeydi. Ne var ki, Çekoslovakya Devlet Başkanı Edvard Beneş yardım talep etmedi. SSCB'yi "istenmeyen müttefik" (nejelatelnıy soyuznik) olarak görüyordu. ${ }^{64}$

SSCB, Münih’te varılan anlaşmayla savaşın ertelendiği kanaatindeydi. İngiltere Başbakanı Chamberlain ise barışı koruduklarını, Almanya'yı “yatıştırdıklarını” düşünüyordu ve gelişmeler eski başbakan, liberal milletvekili Lloyd George’un 21 Kasım 1937’de Sovyet büyükelçi Mayskiy’le yaptığı görüşmede söylediği “Chamberlain, Almanya ve İtalya’yla anlaşmayı, uğruna İspanya’yı, Avusturya'yı, Çekoslovakya’yı ve daha birçoğunu feda edecek kadar önemli sayıyor” sözünü haklı

56 Dokumentı Vneşney Politiki SSSR, Tom 21, s.296.

57 Dokumentı Po İstorii Myunhenskogo Sgovora 1937-1939, s.152-153.

58 Ibid., s.80-82.

59 Dokumentı Vneşney Politiki SSSR, Tom 21, s.436.

60 Dokumentı Po İstorii Myunhenskogo Sgovora 1937-1939, s.174-175.

61 Savaştan sonra SSCB’nin ele geçirdiği Almanya Dışişleri Bakanlığı arşivinden A 2589 nolu rapora ek 10 Temmuz 1938 tarihli politik rapordan aktaran Falsifikatorı İstorii (İstoriçeskaya Spravka), Moskva, Gospolitizdat, 1948, s.2829; Ayrica bkz. "Not a Struggle Against German Aggression but a Policy of Isolating the USSR", http://www. revolutionarydemocracy.org/archive/false2.htm (Erişim Tarihi: 11 Temmuz 2015).

62 Sidorov ve Kleymenova, İstoriya, s.257.

63 Dokumentı Vneşney Politiki SSSR, Tom 21, s.516.

64 Sidorov ve Kleymenova, İstoriya, s.258. 
çıkarıyordu. ${ }^{65} 30$ Eylül 1938'de imzalanan İngiliz-Alman deklarasyonunda iki ülke ilişkilerinin iki taraf ve Avrupa için her şeyden önemli olduğu ve Münih Anlaşması’yla İngiliz-Alman Deniz Anlaşması'nın, tarafların birbirlerine karşı asla savaşa başvurmama niyetinin göstergesi olduğu belirtiliyordu. ${ }^{66}$ Chamberlain aynı gün Londra'ya döndüğünde Almanya'dan onurlu bir barış getirdiğini, barış döneminde olduklarını söylüyor ve herkese evlerine gidip rahatça uyumalarını tavsiye ediyordu. ${ }^{67} 4$ Ekim 1938 tarihli Pravda gazetesi ise, sözde dünyayı kurtaran Chamberlain'in utanmazlığı olarak nitelediği söz konusu anlaşmanın emperyalist savaştan sonra tarihteki yerini aldığı yorumunu yapıyordu. ${ }^{68}$ İngiliz-Alman deklarasyonuna benzer bir deklarasyon 6 Aralık 1938'de Paris'te Fransa ile Almanya arasında da imzalandı. İki ülke arasındaki barışçıl iyi komşuluk ilişkilerinin öneminin vurgulandığı deklarasyonda, aralarında sınır veya toprak anlaşmazlığı bulunmadığının altı çiziliyordu. ${ }^{69}$ Fransa Dışişleri Bakanı Georges Bonnet, Ribbentrop’la görüşmesinin ardından elçilerine "Alman politikasının bundan böyle Bolşevizmle savaş için doğuya yöneldiğini, Almanya’nın doğuya yayılma iradesi gösterdiğini” bildirmişti. ${ }^{70}$

\section{Savaşa Doğru: Nazi-Sovyet Paktı'na Giden Süreç}

Böylelikle İngiltere ve Fransa, Çekoslovakya'dan Almanya'ya toprak transferine razı olurken, Almanya ile ilişkilerini de "dostluk” temeline oturtuyorlardı. Sovyetler Birliği lideri Stalin, 10 Mart 1939'da 18. Parti Kongresi'nde sunduğu raporda, Almanya’ya toprak verilmesinin, bu ülkenin SSCB’ye karş1 savaşa girmesinin bedeli olduğu değerlendirmesini yapıyordu. İngiltere ve Fransa'nın Avrupa'nın kolektif güvenliği için çaba göstermek yerine karışmamayı tercih etmesini (örneğin Almanya'nın SSCB’ye saldırmasına engel olmamayı), saldırıyı özendiren, savaşa imkân veren ve onun dünya savaşına dönüşmesini mümkün kılan bir davranış olduğu tespitini yapıyordu. ${ }^{71}$

15 Mart'ta Hitler, Çekoslovakya’nın tamamını işgal ettiğinde İngiltere ve Fransa bu oldubittiye razı oldular. ${ }^{72}$ Sovyetler Birliği bu olayı, Orta Avrupa'nın siyasi istikrarını zedeleyen keyfi bir saldırı eylemi olarak tanımladı. ${ }^{73}$ Ardından İngiltere, Fransa ve SSCB arasında Hitler'in saldırısı durumunda Doğu Avrupa'nın güvenliğinin nasıl sağlanacağı ile ilgili müzakereler başladı. 21 Mart'ta Chamberlain'in; İngiltere, Fransa, SSCB ve Polonya'nın bağımsızlıkları tehlikeye düştügünde ortak hareket etmek amacıyla birbirlerine danışmalarını içeren dörtlü deklarasyon önerisi, Polonya SSCB desteğini istemediğinden ve Almanya'nın tepkisinden çekindiği için gerçekleşmedi. 31 Mart'ta İngiltere, tek taraflı olarak Polonya’nın toprak bütünlügü için garanti verdi. 17 Nisan'da SSCB;

65 Dokumentı Vneşney Politiki SSSR, Tom 20, İzdatelstvo Politiçeskoy Literaturı, Moskva,1976, s.611.

66 “The Anglo-German Declaration, 30 September 1938”, http://www.iwm.org.uk/collections/item/object/1030005003 (Erişim Tarihi: 11 Temmuz 2015).

67 “Neville Chamberlain 'Peace for Our Time', September 30, 1938”, http://www.britannia.com/history/docs/peacetime. html (Erişim Tarihi: 11 Temmuz 2015).

68 "Hrabriye Mirotvortsı i Deystvitelnaya Borba Za Mir”, Pravda, 4 Ekim 1938, s.1.

69 "The Franco-German Non-Aggression Aggrement”, http://www.oldmagazinearticles.com/Franco-German-NonAggression-Treaty\#.VTdTq8scTIV (Erişim Tarihi: 11 Temmuz 2015).

70 Vilnis Sipols, Diplomatiçeskaya Borba Nakanune Vtoroy Mirovoy Voynı, Mejdunarodnıye Otnoşeniya, Moskva, 1979 , s.211.

71 XVIII Syezd Vsesoyuznıy Kommunistiçeskoy Partii (B), Stenografiçeskiy Otçet, Moskva, Gosudarstvennoye İzdatelstvo Politiçeskoy Literaturı, 1939, s.13-14.

72 İşgale karşı çıkmak bir yana, Britanya Sanayi Federasyonu ile Almanya Sanayi Grubu arasında 16 Mart'ta Düsseldorf'ta iki ülkenin sanayi şirketleri arasında yıkıcı, sağlıksız ekonomik rekabeti önleyen ve yapıcı işbirliği olanaklarını geliştirmeyi amaçlayan bir anlaşma bile imzalandı. Bu konuda bkz. Louis H. Orzack, "The Düsseldorf Agreement: A Study of the Organization of Power and Planning", Political Science Quarterly, Vol.65, No.3, 1950, s.393-414; "British, Nazi Trade Groups Reach Accord”, http://tribappstest.s3-website-us-east-1.amazonaws.com/1939/03/17/page/31/ article/british-nazi-trade-groups-reach-accord (Erişim Tarihi: 11 Temmuz 2015).

73 Dokumentı Vneşney Politiki SSSR, Tom 22, Kn 1, Mejdunarodnıye Otnoşeniya, Moskva, 1992, s.203-204. 
İngiltere ve Fransa'ya Almanya’nın taraflardan birine ve ayrıca Polonya, Romanya, Baltık ülkeleri ve Finlandiya'ya saldırması durumunda birbirlerine ve söz konusu ülkelere yardım etmeyi içeren bir askeri konvansiyon imzalamayı önerdi. Ama İngiltere ve Fransa, Baltık ülkelerine güvence verme niyetinde değildi. Böylece Baltık koridorundan ilerlemesi muhtemel Alman kuvvetleriyle SSCB tek başına savaşmak zorunda kalacaktı. ${ }^{74}$ Fransa Başbakanı Daladier, Chamberlain'in politikasını takip ediyordu. Chamberlain ise SSCB'den pek hazzetmiyordu. 20 Mayıs'ta Dışişleri Bakanlığı Müsteşarı Alexander Cadogan'a, SSCB ile bir askeri ittifak imzalamaktansa istifa etmeyi tercih edeceğini söylemişti. ${ }^{75}$ Kissinger' 1 da belirttiği üzere, Chamberlain SSCB'ye güvenmiyordu, 'Íngiltere'nin özgürlük anlayışıyla uzaktan yakından ilgisi olmayan ve herkesi kulağından yakalama çabasında olan niyetlerinden' kuşkuluydu. ${ }^{76}$ SSCB’nin yeni Dışişleri Bakanı Molotov 31 Mayıs'ta İngiltere ve Fransa'nın davranışını; saldırganın Polonya ve Romanya'ya saldırması halinde SSCB'nin yardımını garantiye alma, buna karşın SSCB’ye ve Baltıkülkelerine yönelik bir saldırı durumunda ne yapacakları sorusuyla ilgilenmeme şeklinde özetliyordu. Ateşe başkalarının eliyle dokunmak isteyenlerin ülkeyi savaşa sürüklemesine izin vermeyeceklerini ifade ediyordu. ${ }^{77}$ Sovyet Politbüro üyesi Andrey Jdanov ise, 29 Haziran'da Pravda'da yayımlanan makalesinde İngiltere ve Fransa'nın samimi olmadığını, SSCB'yi oyaladığını yazıyordu. Ona göre, 75 gündür süren müzakerelerin 59 günü sürüncemeyle geçmişti. Söz konusu iki ülke, eşitlik ve karşılıklılık temelinde bir antlaşma hedeflemiyordu, SSCB'den diplomatik ilişkisinin bulunmadığı Hollanda ve İsviçre için de toprak bütünlügünü koruma garantisi istemişlerdi. Kendisine saygısı olan ve başka devletlerin oyuncağı olmayı aklından bile geçirmeyen Sovyetler Birliği’nin bu tür bir antlaşma imzalaması mümkün değildii. ${ }^{78}$ İngiltere Dışişleri Bakanı Lord Halifax ise Baltık devletlerine verilecek garantinin SSCB'nin Hollanda ve İsviçre’ye vereceği garantiye bağlı olduğunu, Polonya ve Romanya’ya verdikleri garantinin de dolaylı olarak Rusya’nın güvenliğine önemli bir katkı sağladığını söylüyordu. ${ }^{79}$

Halifax 29 Haziran'da Almanya ile sömürge, hammadde, ticaret, hayat sahası ve Avrupalıları ilgilendiren daha birçok tartışmalı sorunu çözmeye hazır olduklarını bildiren bir konuşma yaptı. ${ }^{80}$ 21 Temmuz'da ise, Almanya’nın Londra Büyükelçisi Dirksen, Berlin’e Hitler ve Chamberlain'in danışmanlarının saldırmazlık paktı ve iki ülkenin etki alanlarını belirlemeyi içeren bir karışmazlık paktı konularını görüştüklerini bildirdi. ${ }^{81} 31$ Temmuz'da Berlin'e gönderdiği bir başka raporda ise, İngiltere'nin silahlanarak gücünü artırmaya çalıştığını aynı zamanda Almanya’yla da anlaşma zemini aradığı bilgisini

74 Sidorov ve Kleymenova, İstoriya, s.271-272.

75 Ibid., s.273; Frank McDonough, Neville Chamberlain, Appeasement and the British Road to War, Manchester University Press, Manchester,1998, s.83; Sipols, Diplomatiçeskaya Borba, s.242. Bu konu 19 Mayıs'ta Avam Kamarası'nda tartışılmıştı. Churchill, SSCB ile görüşmelerin gayretsiz/isteksiz yürüdüğ̈nü düşünüyor, Rusya’yla anlaşma imzalanmasına neden itiraz edildiğini anlamadığını, ittifakın tek amacının saldırıya karşı ve saldırı kurbanlarını korumak için direniş göstermek olduğunu ve bu basit öneride kötü olan bir şey olmadığını öne sürüyordu. Lloyd George ve Anthony Eden da Rusya ile acil bir anlaşma imzalanması gerektiğini düşünüyordu. Churchill, The Gathering Storm, s.435, 438.

76 Kissinger, Diplomasi, s.321.

77 "Doklad Predsedatelya Soveta Narodnıh Komissarov i Narodnogo Komissara İnostrannıh Del SSSR V.M. Molotova Na Sessii Verhovnogo Soveta SSSR 'O Mejdunarodnom Polojenii i Vneşney Politike SSSR' 31 Maya 1939 g.”, http:// doc20vek.ru/node/470 (Erişim Tarihi: 11 Temmuz 2015); LLoyd George, Chamberlain Hükümeti’nin müzakerelerle ilgili tutumunu "politik züppelik" olarak tanımlıyor ve SSCB ile anlaşma niyetinde olmadığını düşünüyordu. Louis Grace Shaw, The British Political Elite and the Soviet Union 1937-1939, Frank Cass Publishers, London, 2003, s.174.

78 Andrey Jdanov, “Angliyskoye i Frantsuzskoye Pravitelstva Ne Hotyat Ravnogo Dogovora s SSSR”, http://doc20vek.ru/ node/585 (Erişim Tarihi: 11 Temmuz 2015).

79 E.L. Woodward, R. Butler (eds.), Documents on British Foreign Policy 1919-1939, Series 3, Vol.VI, Her Majesty's Stationary Office, London, 1953, s.145, 173, 225.

80 “Lord Halifax’s Speech on June 29, 1939 on British Foreign Policy”, Bulletin of International News, Vol.16, No.14, 1939, s.8-11.

81 Dokumentı i Materialı Kanuna Vtoroy Mirovoy Voynı 1937-1939, Tom 2, Moskva, Politizdat, 1981, s.141-144. 
veriyordu. ${ }^{82}$ Dirksen'in raporları, İkinci Dünya Savaşı sonunda yenilen Almanya'dan elde edilen dış politika belgelerine dayanıyordu. O dönemde İngiliz basınında (Daily Telegraph ve News Chronicle gazetelerinde) bu gizli raporları doğrulayacak bir haber yayımlandı. Haberde, Eylül ayına kadar İngiliz ve Fransız hükümetleri Almanya'ya 1 milyar sterlin kredi ve Afrika kolonilerinin müşterek paylaşımını içeren bazı önerilerde bulunacakları yazılıydı. Habere göre bu plan, SSCB’nin, İngiltere ve Fransa ile ittifak yapma ihtimalini azaltıyordu. Görünüşe göre Chamberlain ve Daladier ikili oynuyordu ${ }^{83}$ ama yine de bu Sovyet Hükümeti’nin -Almanya ile ticari konularla ilgili görüşmelere başlasa da- İngiltere ve Fransa ile ittifak arayışını sürdürmesine engel olmadı. Ne var ki İngiliz ve Fransız askeri heyetlerinin uçak yerine iki haftalık gemi ve tren yolculuğu sonrası Moskova'ya gelmeleri, imza yetkilerinin bulunmaması, Sovyet Genelkurmay Başkanı Boris Şapoşnikov Alman saldırısı durumunda 136 tümen, 5.000 ağır silah, 9-10.000 tank ve 5.000-5.500 savaş uçağının hazır edileceği ortak harekât planıyla masaya gelirken, muhataplarının deyim yerindeyse eli boş gelmesi, İngiltere ve Fransa'nın SSCB ile ittifak konusunda pek de kararlı olmadığını gösteriyordu. ${ }^{84}$ Dirksen ise ülkesine, Moskova'ya giden askeri heyetin öncelikli görevinin etkili bir anlaşma imzalamaktan ziyade Sovyet ordusunun savaş yeteneğini tespit etmek olduğunu bildiriyordu. ${ }^{85}$ SSCB’ye göre, Polonya’nın işbirliğine karşı çıkması, saldırıya uğradığında Sovyet birliklerinin yardımını istememesi ve bu konuyla ilgili İngiltere ve Fransa'nın açık ve net bir tutum takınmaması görüşmelerin olumlu bir sonuca bağlanmasını engelliyordu. ${ }^{86}$ İngiliz tarafı ise Polonya'yı ikna etmek için elinden geleni yaptığı inancındaydı. Varşova Büyükelçisi Howard Kennard’a göre bu, Rus ve komünizm düşmanlığından kaynaklanıyordu. Halifax ise, Sovyet yardımını reddederek Alman saldırısını önleyebileceğini düşünen Polonya’nın büyük bir yanılgı içerisinde olduğunu düşünüyordu. ${ }^{87}$

17 Ağustos’ta İngiliz tarafının isteğiyle görüşmelere ara verildi. 21 Ağustos'ta Sovyet tarafı yaptığı açıllamada, Birinci Dünya Savaşı’nda nasıl Amerikan ve İngiliz askeri kuvvetleri, Fransa'yla Fransa topraklarında hareket edebilme şartıyla askeri işbirliği yapmayı kabul ettiyse, SSCB’nin de Polonya ve Romanya topraklarından geçebilme şartıyla İngiltere ve Fransa’yla askeri işbirliği yapacağını bildirdi. Bunun "askeri aksiyom" olduğunu, görüşmelere gelen heyetlere böyle temel bir konuda direktif verilmemesini anlayamadıklarını, bunu büyük bir soruna dönüştürmelerinin ve daha uzun bir inceleme taleplerinin SSCB ile askeri işbirliği hususunda istekli olmadıkları yönündeki şüphelerin artmasına neden olduğu, görüşmelere verilen aranın İngiliz ve Fransız tarafını zayıflattığı ifade edildi. ${ }^{88}$

$\mathrm{Bu}$ arada, sürmekte olan ticari konularla ilgili Sovyet-Alman görüşmelerinden 19 Ağustos'ta bir anlaşma ortaya çıktı. ${ }^{89}$ Dahası Sovyetler Birliği, İngiltere ve Fransa'yla uzlaşamadı̆̆ı bir dönemde saldırı tehdidi aldığı Almanya'dan saldırmazlık antlaşması teklifi alınca bunu olumlu değerlendirdi.

82 Documents on German Foreign Policy 1918-1945, Series D (1937-1945), Vol.VI, Her Majesty’s Stationery Office, London, 1956, s.1024.

83 Anna Pankratova ve Vladimir Potemkin, “SSSR-Deystvitelnıy Faktor Mira 1939 g.", İstoriya Diplomatii Tom 3, s.688; Söz konusu haberin 22 Temmuz 1939 tarihli The Mail gazetesindeki yansıması için bkz: "To Appease Hitler; Unofficial Scheme”, http://trove.nla.gov.au/ndp/del/article/55914558 (Erişim Tarihi: 11 Temmuz 2015).

84 Myagkov, “Ot Myunhenskogo”, s.55-56; Sipols, Diplomatiçeskaya Borba, s.263; İgor Ovsyanıy, Tayna, V Kotoroy Voyna Rojdalas, Politizdat, Moskva,1971, s.276-277.

85 Ovsyanı, Tayna, V Kotoroy Voyna Rojdalas, s.271.

86 Myagkov, “Ot Myunhenskogo”, s.57; Sipols, Diplomatiçeskaya Borba, s.267.

87 E.L. Woodward, R. Butler (eds.), Documents on British Foreign Policy 1919-1939, Series 3, Vol.VII, Her Majesty's Stationary Office, London,1954, s.87-89.

88 Ovsyaniy, Tayna, V Kotoroy Voyna Rojdalas, s.277-278.

89 Anlaşma, Almanya’nın SSCB’ye yedi yıllığına 200 milyon mark tutarında kredi sağlamasını bunun \%5'i ile anlaşmanın imzalandığı günden itibaren iki yıl boyunca SSCB’nin Alman ürünleri satın almasını öngörüyordu. Ayrıca anlaşma SSCB'den Almanya'ya yine ilk iki yıl boyunca 180 milyon marklık ürün tedarikini içeriyordu. Almanya hem kendi ürünlerine pazar aryyor, hem de Sovyet hammadde kaynaklarıla ilgileniyordu. Pankratova ve Potemkin, "SSSRDeystvitelnıy", s.688-689. 
Çünkü Naziler hem kendisine saldırmayacağını söylüyor hem de Baltık bölgesine yönelik bir talebinin olmadığını bildiriyordu. ${ }^{90}$ Bu çerçevede 23 Ağustos'ta SSCB Dışşsleri Bakanı Molotov ile Almanya Dışişleri Bakanı Ribbentrop Moskova'da Nazi-Sovyet Saldırmazlık Paktı'nı imzaladılar. Antlaşma, tarafların birbirlerine saldırmamasını, taraflardan biri üçüncü bir devletin saldırısına uğradığı takdirde diğer tarafin üçüncü devlete destek vermemesini içeriyordu. Gizli ek protokole göre ise, siyasal değişiklik ya da toprak değişikliği durumunda Baltık bölgesi (Litvanya, Letonya, Estonya, Finlandiya) ile Polonya'da Narew, Vistula ve San ırmaklarının oluşturduğu hattın doğusu (kabaca Varşova'nın doğusu) SSCB nüfuz alanı olacaktı. ${ }^{91}$

Ticari anlaşmanın siyasi bir güvence kazanmasını da sağlayan bu pakt, İngiltere ve Fransa ile gerçekleştirilen ve sonuca ulaşmayan müzakerelerden farklı bir içeriğe sahipti. Karşılıklı yardımı içeren bir ittifak anlaşması değildi. Molotov, 31 Ağustos'ta SSCB Yüksek Sovyeti’nde yaptığı konuşmada, İngiltere ve Fransa’nın samimi davranmadığını, müzakereleri ağırdan aldığını, Moskova’ya imza yetkisi olmayan askeri heyet gönderdiğini söyledi. Sovyet karşıtı bir tutum izleyen Polonya’nın İngiltere ve Fransa'nın direktifleri doğrultusunda hareket ettiğini ve müzakereler çıkmaza girdiği için Almanya'yla saldırmazlık paktının imzalandı̆̆ını ifade etti. ${ }^{92}$

\section{Sonuç Yerine: İşgalin Sorumlusu Nazi-Sovyet Paktı mı?}

Birinci Dünya Savaşı sonrası kurulan düzenin başta gelen iki aktörü İngiltere ve Fransa, Nazi Almanya'sının kendileri ve Avrupa için büyük bir tehdit olduğunu düşünmediler, bu ülkeye karşı yatıştırma politikası izlediler ve Almanya’nın giderek (özellikle askeri alanda) güçlenmesine göz yumdular. Avrupa'da barışın Alman taleplerinin karşılanmasıyla sağlanacağı fikrine sahiptiler, daha doğrusu uyguladıkları politikayı bu şekilde meşrulaştırıyorlardı. Ama bu durum, Nazilerin, -hele doğuya doğru yayılmaya başladıktan sonra- Sovyetler Birliği’ne saldırması, faşistlerle komünistlerin savaşı ve hatta komünistlerin yenilgisi şeklindeki bir ihtimale/beklentiye ardına kadar açı bir kapı bırakıyordu. Bu çerçevede, Sovyetler, Nazilerin güçlenmesine izin veren hatta destek olanları İkinci Dünya Savaşı'nın sorumlusu olarak gördü. İşte Putin'in Nazi-Sovyet Paktı'nı savunan söz konusu demeci, bunun diplomatik bir dille ifadesiydi.

Burada iki önemli husus var. İlk olarak, Sovyetler Birliği, İngiltere ve Fransa ile ittifak anlaşması yapmak yerine neden Nazilerle saldırmazlık paktı imzaladığı sorusunun cevabı üzerinde durmak gerekir. Bu sorunun cevabının bir kısmı (İngiltere ve Fransa ile ittifak yapmamasının/ yapamamasının nedenleri) yukarıda verildi. Nazilerle saldırmazlık paktı imzalanması ise gelinen noktada söz konusu uluslararası ortamın Sovyetleri kendi güvenliğini garanti altına almak için bir tercih yapmaya zorlamasından kaynaklandı. Sovyetler Birliği, saldırmazlık antlaşması önerisini kabul edip belli bir süre savaşı kendinden uzak tutarak bu sürede güçlenme firsatı bulma ile öneriyi reddederek tümüyle tecrit olacağı uluslararası ortamda Batılıların, Almanya’yı kendisine karşı kışkırtmalarına olanak sağlama seçenekleriyle karşı karşıya olduğunu ve haklı sebeplere dayanarak ilkini tercih ettiğini ifade ediyordu..$^{93}$

90 Documents on German Foreign Policy 1918-1945, Series D (1937-1945), Vol. VII, Her Majesty's Stationery Office, London, 1956, s.63, 84.

91 Dokumentı Vneşney Politiki SSSR, Tom 22, s.630-632; Edward Acton ve Tom Stableford, The Soviet Union A Documentary History, Vol.2, University of Exeter Press, Exeter, 2007, s.6-8.

92 Ayrıca Molotov, Almanya’yla yapılan ticari anlaşma için de, daha önce İngiltere, Fransa ya da başka herhangi bir ülkeyle ekonomik açıdan bu derece kazançlı bir anlaşma imzalamadıklarını söylüyordu. Vyaçeslav Molotov, "Speech Delivered on 31 August 1939”, https://www.marxists.org/archive/molotov/1940/peace.htm (Erişim Tarihi: 11 Temmuz 2015).

93 Falsifikatori İstorii, s.53. 
İkincisi husus ise, Nazilerle yapılan saldırmazlık paktının, Sovyetler Birliği’nin uzun zamandan beri tasarladığı bir dış politika faaliyeti/hamlesi olup olmadığı sorusudur. Aslında ilk sorunun cevabının, bu sorunun cevabı için de geçerli olduğu söylenebilir. Yine de Sovyetlerin uzun zamandır Nazilerle böyle bir pakt tasarladığını kanıtlayacak herhangi bir bilgi, belge olmadığını belirtmek gerekir.

Nazi Almanya’sının güçlenmesine açıkça karşı duran Sovyetler Birliği, Batılı devletlerle eşitlik temelinde kolektif güvenliği sağlamak amacıyla anlaşmalar imzalamak için büyük çaba gösterirken İngiltere ve Fransa saldırıyı doğuya, Sovyetler Birliği'ne yöneltme politikası izlemeyi tercih etti. ${ }^{94}$ 12 Mayıs 1939'da Hitler, Ribbentrop'tan SSCB ile ilişkilerde 1922'de imzalanan ve yalnız iki ülkeyi yakınlaştıran antlaşmaya atıfla yeni bir Rapallo atmosferini oluşturmasını istese de ${ }^{95}$ gelinen noktada SSCB ile Almanya arasında gerçek bir yakınlaşma yaşandığını söylemek güçtü. Sovyet-Alman ilişkilerinde olumlu bir gelişme olarak addedilebilecek Alman Dışişleri Bakan Yardımcısı Ernst von Weizsacker ile SSCB Berlin Büyükelçisi Aleksey Merekalov'un 17 Nisan'da gerçekleştirdikleri görüşmeden beş hafta sonra Weizsacker günlüğüne, Ribbentrop’a Sovyet-İngiliz-Fransız ilişkilerinin gelişmesini ve bağlayıcılığını engellemek gerektiğini bildirdiğini yazıyordu. Propaganda Bakanı Joseph Goebbels; Sovyet Dışişleri Bakanı Litvinov'un 3 Mayıs 1939'da görevden alınmasıyla ilgili birçok tahmin yürütüldüğü dönemde günlügüne "Londra ve Paris, SSCB’nin bize yönelmek istediğini sanıyor, biz de gerilimi ve endişeyi artırmak için bunu yalanlamıyoruz.” şeklinde not almıştı. Bununla birlikte, 5 Mayıs'tan itibaren Almanya, Sovyet karşıtı söylem ve yayınlara ikinci bir emre kadar son veriyordu. ${ }^{96}$ Yine de Yahudi Dışişleri Bakanı Litvinov'un görevden alınması Sovyet dış politikasında keskin bir değişime neden olmadı. Moskova gelen önerileri birkaç gün içinde cevaplarken, örneğin Londra'nın cevapları birkaç haftayı buluyordu. Hatta yeni Dışişleri Bakanı Molotov, İngiliz Büyükelçi William Seeds’e askeri görüşmelerin başlaması için baskı yapmıştı. Almanya'nın Moskova Büyükelçisi Schulenburg'un ticari anlaşma için müzakerelere başlanması teklifini, Almanya ile yakın zamanda başlayan bu tür birkaç görüşmenin sonuçsuz kaldığını, Alman Hükümeti'nin bir çeşit oyun oynadığını söyleyerek reddetmişti. ${ }^{97}$ Bununla birlikte Molotov'un 31 Ağustos'ta Yüksek Sovyet'te yaptığı konuşmada, Nazi-Sovyet Paktı'nın Stalin'in 18. Kongre'de söylediği barıştan ve bütün ülkelerle ekonomik ilişkilerin güçlendirilmesinden yana olduklarına dair sözleriyle örtüştüğünü belirtmesi, ${ }^{98}$ SSCB’nin henüz Mart ayında Almanya ile yakınlaşma isteğini gösteren bir sinyal olduğuna yönelik bir yorumun yapılmasına imkân verdi. Hâlbuki Stalin bu politikayı, SSCB'nin çıkarlarının ihlal edilmemesi şartına bağlamış, 1935'te Fransa'yla, 1936'da

94 Ibid., s.54; Ayrıca, bu süreçte birçok uluslararası şirketin Nazi Almanya’sının askeri, ekonomik gelişmesine ve silahlanmasına katkı sağladığını belirtmek gerekir. Yaman Törüner, "Nazilere Kimler Yardım Etti?” http://www. milliyet.com.tr/nazilere-kimler-yardim-etti-/ekonomi/ydetay/2004462/default.html (Erişim Tarihi: 11 Temmuz 2015); “Nazilere Yardım Eden Büyük Firmalar”, http://www.netgazetesi.net/nazilere-yard\%C4\%B1m-edenb\%C3\%BCy\%C3\%BCk-firmalar.html (Erişim Tarihi: 11 Temmuz 2015); Andrey Gromıko, Vneşnyaya Ekspansiya Kapitala, Istoriya i Sovremennost, Misl, Moskva, 1982, s.164-179.

95 Sidorov ve Kleymenova, İstoriya, s.275.

96 Sergey Sluç, "Vneşnepolitiçeskaya Strategiya Gitlera v 1939 Gody i Sovyetskiy Soyuz”, Mejdunarodnıy Krizis 1939-1941 gg.: Ot Sovetsko-Germanskih Dogovorov 1939 Goda Do Hapadeniya Germanii Na SSSR, s.70-71.

97 Jonathan Haslam, "Soviet-German Relations and the Origins of the Second World War: The Jury Is Still Out", The Journal of Modern History, Cilt 69, No.4, 1997, s.793; Derek Watson, "Molotov’s Apprenticeship in Foreign Policy: The Triple Alliance Negotiations in 1939”, Europe-Asia Studies, Cilt 52, No.4, 2000, s.699; Geoffrey Roberts, “The Soviet Decision for a Pact with Nazi Germany”, Soviet Studies, Cilt 44, No.1, 1992, s.62; Roberts'a göre Temmuz 1939'dan önce Sovyetlerin politika değişiminden bahsetmek mümkün değildi. O zamana kadar Sovyetler, Almanların politik ilişkileri iyileştirmeye yönelik girişimlerini kayıtsızlıkla ve kuşkuyla karşılamıştı. Ibid., s.61.

98 Molotov, "Speech Delivered on 31 August 1939", https://www.marxists.org/archive/molotov/1940/peace.html (Erişim Tarihi: 11 Temmuz 2015). 
Moğolistan'la ve 1937'de Çin Cumhuriyeti'yle yapılan paktları saydıktan sonra bu sözleri söylemiş ve devamında saldırganlardan korkmadıklarını, Sovyet sınırının dokunulmazlığını ihlal edenlerin bir vuruşuna iki vuruşla karşılık vermeye hazır olduklarını da eklemişti. ${ }^{99}$ Molotov ise bunu faşist bir ülkeyle yapılan paktı savunmak amacıyla söylüyor, SSCB’nin genel politika söylemine uygun bir anlaşma olduğunun altını çizmeye çalışıyordu. Zaten diğer ülkelerle barış ve ekonomik ilişkilerin geliştirilmesi söylemi, 1920'li yılların başından itibaren (ve tabii 1934'teki 17. Parti Kongresi'nde de) sıkça ortaya konmuştu. Yine 18. Kongre'de Stalin, Almanların Sovyet Ukrayna'sını ele geçirecekleri yönünde İngiliz, Fransız ve Kuzey Amerika basınında çıkan ve yaygara koparan haberlerle ilgili, Batılı devletlerin görünürde bir neden yokken Almanya ile SSCB arasında çatışma yaratmaya çalıştıkları yorumunu yapıyordu. ${ }^{100}$ Bunu, Almanya ile yakınlaşma isteğinden ziyade, Batılıların, Almanları SSCB’ye saldırtma hevesini söz konusu örnekle açığa çıkarma çabası olarak değerlendirmek mümkündü. Zira SSCB, Almanya dâhil hiçbir ülkeyle savaşmak istemiyordu.

Her şey bir yana, şunu özellikle belirtmek gerekir ki, 1939 yılında özellikle Çekoslovakya'nın da Alman topraklarına katılmasından sonra, Nazi-Sovyet Paktı’nın nasıl ve niçin imzalandığını sorgulamanın bir önemi yoktu. Önceki yıllara kıyasla başta SSCB ve Avrupa ülkeleri için çok daha büyük bir tehdit haline gelen Almanya ile yapılan pakta şaşırmamak gerekir. SSCB’nin düşmanı, çıkarları doğrultusunda SSCB'ye saldırmazlık paktı teklif etmiş, İngiltere ve Fransa'nın veremediği güvenceleri vermiş ve SSCB de sosyalist anavatanın çıkarları gereği bunu kabul etmişti. 1933'ten 1939’a Nazilere yönelik hep hoşgörülü bir politika izleyen ve SSCB ile ittifak yapmakta tereddüt eden söz konusu iki devlete güvenmek de bu bağlamda yeterince riskli bir işti. Zira daha önce de belirtildiği üzere, SSCB’yi bu pakttan dolayı eleştiren İngiltere, 1938'de Münih Anlaşması'ndan hemen sonra, Fransa da Aralık ayında Almanya ile saldırmazlık deklarasyonu imzalamışlardı. Bu deklarasyonları ve 1933'ten beri Almanya'ya yönelik hoşgörülü politikayı unutup Nazi Sovyet Paktı'nı ve SSCB'yi eleştirmenin hakkaniyete uygun bir davranış olmadığı aşikârdı. Bu paktla savaşı kendinden iki yıl uzak tutmayı başaracak olan Sovyetler Birliği, Nazilerin mağlup edilmesinde büyük pay sahibi olacaktı.

Sonuç olarak, Nazi-Sovyet Paktı ya da bu paktı imzaladığı için Sovyetler Birliği savaşın/Nazi işgalinin sorumlusu değildi. Nazi işgalinin sorumlusu, bu paktın gerçekleşmesine olanak sağlayan, Sovyetleri bu paktı imzalamaya mecbur bırakan 1933'ten 1939'a uluslararası politikada yaşanan gelişmelerdi. Bir başka deyişle bu döneme hâkim olan uluslararası politik ortamdı.

99 XVIII Syezd Vsesoyuznıy Kommunistiçeskoy Partii (B), s.15.

100 Ibid., s.13-14. 


\section{Kaynakça}

\section{Resmi Yayınlar}

Documents on British Foreign Policy 1919-1939, Series 3, Vol. VI, eds. E.L. Woodward, R. Butler, London, Her Majesty's Stationary Office, 1953.

Documents on British Foreign Policy 1919-1939, Series 3, Vol. VII, eds. E.L. Woodward, R. Butler, London, Her Majesty's Stationary Office, 1954.

Documents on German Foreign Policy 1918-1945, Series D (1937-1945), Vol. VI, London, Her Majesty's Stationery Office, 1956.

Documents on German Foreign Policy 1918-1945, Series D (1937-1945), Vol. VII, London, Her Majesty's Stationery Office, 1956.

Dokumentı i Materialı Kanuna Vtoroy Mirovoy Voyn 1937-1939, Tom 1, Moskva, Politizdat, 1981.

Dokumentı i Materialı Kanuna Vtoroy Mirovoy Voyn 1937-1939, Tom 2, Moskva, Politizdat, 1981.

Dokumentı Po İstorii Myunhenskogo Sgovora 1937-1939, Moskva, İzdatelstvo Politiçeskoy Literaturı, 1979.

Dokumentı Vneşney Politiki SSSR, Tom 16, Moskva, İzdatelsko Politiçeskoy Literaturı, 1970.

Dokumentı Vneşney Politiki SSSR, Tom 17, Moskva, İzdatelstvo Politiçeskoy Literaturı, 1971.

Dokumentı Vneşney Politiki SSSR, Tom 18, Moskva, İzdatelstvo Politiçeskoy Literaturı, 1973.

Dokumentı Vneşney Politiki SSSR, Tom 19, Moskva, İzdatelstvo Politiçeskoy Literaturı, 1974.

Dokumentı Vneşney Politiki SSSR, Tom 20, Moskva, İzdatelstvo Politiçeskoy Literaturı, 1976.

Dokumentı Vneşney Politiki SSSR, Tom 21, Moskva, İzdatelstvo Politiçeskoy Literaturı, 1977.

Dokumentı Vneşney Politiki SSSR, Tom 22, Kn. 1, Moskva, Mejdunarodnıye Otnoşeniya, 1992.

Falsifikatorı İstorii (İstoriçeskaya Spravka), Moskva, Gospolitizdat, 1948.

Gromıko, Andrey. Vneşnyaya Ekspansiya Kapitala, İstoriya i Sovremennost, Moskva, Misl, 1982.

Molotov, Vyaçeslav. Stati i Reçi 1935-1936, Moskva, Partizdat TsK VKP(B), 1937.

Ovsyanıy, İor. Tayna, V Kotoroy Voyna Rojdalas, Moskva, Politizdat, 1971.

Politbüro TsK RKP(B)-VKP(B) i Yevropa, Reşeniya Osoboy Papki 1923-1939, Moskva, Rosspen, 2001.

Potemkin, Vladimir (red.) İstoriya Diplomatii, Tom 3, Moskva-Leningrad, Gosudarstvennoye İzdatelstvo Politiçeskoy Literaturı, 1945.

Sipols, Vilnis. Diplomatiçeskaya Borba Nakanune Vtoroy Mirovoy Voynı, Moskva, Mejdunarodnıye Otnoşeniya, 1979.

VII Kongress Kommunistiçeskogo Internatsionala i Borba Protiv Faşizma i Voynı, Moskva, İzdatelstvo Politiçeskoy Literaturı, 1975.

XVIII Syezd Vsesoyuznıy Kommunistiçeskoy Partii (B), Stenografiçeskiy Otçet, Moskva, Gosudarstvennoye İzdatelstvo Politiçeskoy Literaturı, 1939.

\section{Süreli Yayın}

İzestiya, 20 Eylül 1934.

Pravda, 28 Mayıs 1934.

Pravda, 16 Ekim 1936.

Pravda, 4 Ekim 1938.

\section{Diğer Yayınlar}

Acton, Edward ve Tom Stableford. The Soviet Union A Documentary History, Cilt 2, University of Exeter Press, Exeter, 2007.

Carr, Edward Hallet. Komintern ve İspanya İç Savaşı, çev: Ali Selman, İletişim Yayınları, İstanbul, 2010. 
Churchill, Winston. The Gathering Storm, New York, Rosettabooks, 2002.

Ellman, Michael ve Sergei Maksudov. "Soviet Deaths in the Great Patriotic War: A Note", Europe-Asia Studies, Cilt 46, No.4, 1994, s.671-680.

Haslam, Jonathan. "Soviet-German Relations and the Origins of the Second World War: The Jury Is Still Out", The Journal of Modern History, Cilt 69, No.4, 1997, s.785-797.

Kissinger, Henry. Diplomasi, İbrahim H. Kurt (Çev.), Türkiye İş Bankası Kültür Yayınları, İstanbul, 2007.

“Lord Halifax's Speech on June 29, 1939 on British Foreign Policy”, Bulletin of International News, Cilt 16, No.14, 1939, s.8-11.

McDonough, Frank. Neville Chamberlain, Appeasement and the British Road to War, Manchester University Press, Manchester, 1998.

Myagkov, Mihail. "Ot Myunhenskogo Soglaşeniya Do Sovetsko-Germanskogo Dogovora Ot 23 Avgusta 1939 g.: Predıstoriya Voprosa”, Mejdunarodniy Krizis 1939-1941 gg.: Ot Sovetsko-Germanskih Dogovorov 1939 Goda Do Hapadeniya Germanii Na SSSR, (red.) N. Yegorova, A. Zagorskiy et.al., İzdatelstvo Prava Çeloveka, Moskva, 2006, s.47-60.

Orzack, Louis H. "The Düsseldorf Agreement: A Study of the Organization of Power and Planning”, Political Science Quarterly, Cilt 65, No.3, 1950, s.393-414.

Quigley, Carroll. The Anglo-American Establishment, Books in Focus, New York, 1981.

Roberts, Geoffrey. “The Soviet Decision for a Pact with Nazi Germany”, Soviet Studies, Cilt 44, No.1, 1992, s.57-78.

Sander, Oral. “Tarihte Yöntem”, Ankara Üniversitesi SBF Dergisi, Cilt 28, Sayı 4, 1973, s.59-71.

Shaw, Louis Grace. The British Political Elite and the Soviet Union 1937-1939, Frank Cass Publishers, London, 2003.

Sidorov, Andrey ve Nadejda Kleymenova. İstoriya Mejdunarodnıh Otnoşeniy 1918-1939, Tsentrpoligraf, Moskva, 2008.

Sluç, Sergey. "Vneşnepolitiçeskaya Strategiya Gitlera v 1939 Gody i Sovyetskiy Soyuz”, Mejdunarodnıy Krizis 1939-1941 gg.: Ot Sovetsko-Germanskih Dogovorov 1939 Goda Do Hapadeniya Germanii Na SSSR, (red.) N. Yegorova, A. Zagorskiy et al., Moskva, İzdatelstvo Prava Çeloveka, 2006, s.61-92.

Sosyalizm ve Toplumsal Mücadeleler Ansiklopedisi, Cilt 3, İletişim Yayınları, İstanbul,1988.

Stalin, Josef. Leninizmin Sorunları, İ. Yarkın, S. Kaya, S. N. Kaya (Çev.), İnter Yayınları, İstanbul,1997.

Watson, Derek. "Molotov's Apprenticeship in Foreign Policy: The Triple Alliance Negotiations in 1939", EuropeAsia Studies, Cilt 52, No.4, 2000, s.695-722.

\section{Internet}

“British, Nazi Trade Groups Reach Accord”, http://tribappstest.s3-website-us-east-1.amazonaws.com/1939/ 03/17/page/31/article/british-nazi-trade-groups-reach-accord (Erişim Tarihi: 11 Temmuz 2015).

"Doklad Predsedatelya Soveta Narodnıh Komissarov i Narodnogo Komissara İnostrannıh Del SSSR V.M. Molotova Na Sessii Verhovnogo Soveta SSSR ‘O Mejdunarodnom Polojenii i Vneşney Politike SSSR' 31 Maya 1939 g., http://doc20vek.ru/node/470 (Erişim Tarihi: 11 Temmuz 2015).

Donovan, John. "Evidence of Royal Dutch Shell/Deterding Financial Support for the Nazis", http:// royaldutchshellplc.com/2010/11/06/royal-dutch-shell-and-the-nazis-part-5-evidence-of-shelldeterdingfinancial-support-for-the-nazis-2/ (Erişim Tarihi 11 Temmuz 2015).

"Foreign Affairs", http://hansard.millbanksystems.com/commons/1938/feb/22/foreign-affairs\#S5CV 0332P0_19380222_HOC_313 (Erişim Tarihi: 11 Temmuz 2015).

Jdanov, Andrey. “Angliyskoye i Frantsuzskoye Pravitelstva Ne Hotyat Ravnogo Dogovora s SSSR”, http:// doc20vek.ru/node/585 (Erişim Tarihi: 11 Temmuz 2015). 
Molotov, Vyaçeslav. “Speech Delivered on 31 August 1939”, https://www.marxists.org/archive/molotov/1940/ peace.htm (Erişim Tarihi: 11 Temmuz 2015).

"Nazilere Yardım Eden Büyük Firmalar”, http://www.netgazetesi.net/nazilere-yard\%C4\%B1m-edenb\%C3\%BCy\%C3\%BCk-firmalar.html (Erişim Tarihi: 11 Temmuz 2015).

“Neville Chamberlain 'Peace for Our Time', September 30, 1938”, http://www.britannia.com/history/docs/ peacetime.html (Erişim Tarihi: 11 Temmuz 2015).

"Not a Struggle Against German Aggression but a Policy of Isolating the USSR", http://www. revolutionarydemocracy.org/archive/false2.htm (Erişim Tarihi: 11 Temmuz 2015).

"Sir H. Deterding, 72 Dies in Swiss Home”, http://royaldutchshellplc.com/1939/02/06/sir-h-deterding-72dies-in-swiss-home/ (Erişim Tarihi 11 Temmuz 2015).

“The Anglo-German Declaration, 30 September 1938”, http://www.iwm.org.uk/collections/item/ object/1030005003 (Erişim Tarihi: 11 Temmuz 2015).

“The Franco-German Non-Aggression Aggrement”, http://www.oldmagazinearticles.com/Franco-GermanNon-Aggression-Treaty\#.VTdTq8scTIV (Erişim Tarihi: 11 Temmuz 2015).

“To Appease Hitler; Unofficial Scheme”, http://trove.nla.gov.au/ndp/del/article/55914558 (Erişim Tarihi: 11 Temmuz 2015).

Törüner, Yaman. "Nazilere Kimler Yardım Etti?” http://www.milliyet.com.tr/nazilere-kimler-yardim-etti-/ ekonomi/ydetay/2004462/default.html (Erişim Tarihi: 11 Temmuz 2015).

"Vstreça c Molodımi Uçonımi i Prepodavatelyami İstorii", http://kremlin.ru/events/president/news/46951 (Erişim Tarihi 11 Temmuz 2015). 